\title{
PENINGKATAN KEPUASAN DAN KINERJA PERAWAT MELALUI SUPERVISI KEPALA RUANGAN
}

\author{
Estelle Lilian Mua ${ }^{1,2 *}$, Rr. Tutik Sri Hariyati ${ }^{3}$, Efy Afifah $^{3}$ \\ 1. Akademi Perawat Bala Keselamatan Palu, Sulawesi Tengah 94112, Indonesia \\ 2. Program Studi Magister Fakultas Ilmu Keperawatan Universitas Indonesia, Depok 16424, Indonesia \\ 3. Fakultas Ilmu Keperawatan Universitas Indonesia, Depok 16424, Indonesia \\ *Email: eslinmua@gmail.com
}

\begin{abstract}
Abstrak
Fenomena di sebuah Rumah Sakit di Palu, supervisi, kepuasan kerja, dan kinerja perawat belum optimal. Penelitian ini bertujuan mengetahui pengaruh pelatihan supervisi klinik terhadap kepuasan kerja dan kinerja perawat di RS tersebut. Penelitian menggunakan quasi experiment pre-post test design with control group. Sampel tiap kelompok 32 perawat dan 56 dokumen. Intervensi yang dilakukan adalah pelatihan supervisi klinik. Hasil penelitian menunujukkan adanya peningkatan yang bermakna $(\mathrm{p}=0,000 ; \alpha=0,05)$ pada supervisi klinik. Supervisi klinik berdampak pada kepuasan kerja dan kinerja perawat $(\mathrm{p}=0,000 ; \alpha=$ $0,05)$. Analisis lanjut menunjukkan ada perbedaan kepuasan kerja dan kinerja perawat $(\mathrm{p}=0,000 ; \alpha=0,05)$ antara kelompok intervensi dan kontrol. Penelitian menyimpulkan ada pengaruh pelatihan supervisi klinik terhadap kepuasan kerja dan kinerja perawat. Rekomendasi hasil penelitian ini adalah untuk terus mempertahankan penerapan supervisi klinik kepala ruangan dengan cara pembinaan, monitoring, dan evaluasi secara berkelanjutan..
\end{abstract}

Kata kunci: kepuasan kerja, kinerja, supervisi, perawat

\begin{abstract}
The phenomenon in a Palu's hospital about supervision, working satisfaction, and clinical performance by nursing staff has not been improved. The purpose of this study was to identify the influence of clinical supervision training on the working satisfaction and clinical performance of nursing in the hospital in Palu. This study used quasi experiment with pre and posttest design with control group. The sample into groups of 32 nurses and 56 document. Intervention that was given to the sample (intervention group) was training supervision.. The result showed that the clinical supervision by head nurse was significantly increased $(p=0,000 ; \alpha=0,05)$ after training and supervision. Clinical supervision that accurately implemented gave influence significantly $(p=0,000 ; \alpha=0,05)$. Further analysis showed the significantly difference on working satisfaction and clinical performance of staff nurses between intervention and control groups $(p=0,000 ; \alpha=0,05)$. Conclusion of this study showed that there influence clinical supervision training working satisfaction and clinical performance of nurses. The recommendation of suggested that maintaining implementation of clinical supervision by head nurse should be improved by supervision, monitoring, and evaluation.
\end{abstract}

Keywords: working satisfaction, clinical performance, supervision, nurse

\section{Pendahuluan}

Supervisi merupakan bagian fungsi pengarahan yang mempunyai peran untuk mempertahankan agar segala kegiatan yang telah terprogram dapat dilaksanakan dengan baik dan lancar. Supervisi dalam keperawatan bukan hanya sekedar kontrol, tetapi lebih dari itu, kegiatan supervisi mencakup penentuan kondisi-kondisi atau syarat-syarat personal maupun material yang diperlukan untuk tercapainya suatu tujuan asuhan keperawatan secara efektif dan efisien (Marquis \& Huston, 2010).
Beberapa penelitian menyimpulkan salah satu faktor yang mempengaruhi kepuasan kerja adalah supervisi. Penerapan supervisi yang tepat akan menyebabkan perawat pelaksana merasa diterima, dihargai, dan dilibatkan sehingga timbul komitmen tinggi untuk memajukan pelayanan keperawatan. Penelitian Saljan (2005) menyimpulkan bahwa ada pengaruh yang bermakna antara peran supervisor sebagai penilai dengan kinerja perawat. Penelitian yang dilakukan oleh Izzah (2003) menunjukkan ada hubungan frekuensi kegiatan supervisi dengan kinerja perawat pelaksana di ruang rawat inap RSUD Batang Jawa Tengah. 
Penelitian lainnya yang dilakukan oleh Mularso (2006) mengenai supervisi keperawatan di rumah sakit Dr. A. Aziz Singkawang menemukan bahwa kegiatan supervisi lebih banyak pada kegiatan pengawasan bukan pada kegiatan bimbingan, observasi dan penilaian. Studi yang dilakukan oleh Supratman dan Sudaryanto (2008) menunjukkan pelaksanaan supervisi keperawatan di berbagai rumah sakit belum optimal dan fungsi manajemen tidak mampu diperankan oleh perawat di sebagian besar rumah sakit di Indonesia. Supratman dan Sudaryanto (2008) mengemukakan bahwa model supervisi klinik keperawatan di Indonesia belum jelas seperti apa dan bagaimana implementasi di rumah sakit. Belum diketahui juga model yang sesuai dan efektif yang dapat diterapkan.

Salah satu model supervisi keperawatan klinik yaitu model academic. Model academic bertujuan untuk membagi pengalaman supervisor kepada para perawat sehingga ada proses pengembangan kemampuan profesional. Farington (1995) yang memperkenalkan tiga kegiatan yang dilakukan oleh supervisor pada supervisi klinik dengan model academic, yaitu educative, supportive, dan managerial.

Pemahaman dan implementasi supervisi model academic dapat dilakukan melalui pelatihan. Kepala ruangan perlu melakukan peningkatan pengetahuan, keterampilan, dan kemampuan karena selalu ada cara yang lebih baik untuk meningkatkan produktivitas kerja yang bermuara pada peningkatan produktivitas organisasi secara keseluruhan. Efek pelatihan bermanfaat bagi individu dan organisasi (Siagian, 2009).

Rumah sakit dalam penelitian ini adalah rumah sakit swasta pertama dan terbesar di Sulawesi Tengah yang selama ini telah menjadi mitra pemerintah yang senantiasa terlibat aktif dalam upaya mendukung program peningkatan derajat kesehatan masyarakat. Rumah sakit Woodward memiliki 110 tempat tidur yang tersebar pada tujuh ruang rawat inap. Selain itu, rumah sakit memiliki sebelas ruang poliklinik dan enam ruang penunjang medik, yaitu laboratorium, radiologi, apotik, kamar operasi, fisiotherapi, dan instalasi gizi. Data eksekutif pelayanan klien rawat inap tahun 2001 sampai 2010 menunjukkan rata-rata Bed Occupancy Rate (BOR) 50,86\%, Averange Length of Stay (ALOS) 3,82 hari, dan Turn Over Interval (TOI) 3,48 hari.

Fenomena di rumah sakit tersebut, supervisi yang dilakukan oleh kepala ruangan belum optimal, kepuasan kerja dan kinerja perawat pelaksana masih rendah. Pelatihan supervisi perlu dilakukan untuk memberikan pemahaman tentang peran supervisor dan melatih kemampuan supervisor dalam memberikan supervisi. Penerapan supervisi didesain dalam bentuk educative, supportive, dan managerial.

Penelitian ini dilakukan untuk mengetahui pengaruh pelatihan supervisi terhadap kepuasan kerja dan kinerja perawat pelaksana, sehingga rumusan masalahnya adalah "apakah penerapan supervisi klinik kepala ruangan dalam bentuk educative, supportive, dan managerial dapat berpengaruh terhadap kepuasan kerja dan kinerja perawat pelaksana di ruang rawat inap sebuah rumah sakit di Palu".

\section{Metode}

Penelitian ini menggunakan metode penelitian quasi experiment dengan pendekatan pre-post test design with control group untuk melihat pengaruh penerapan supervisi dalam bentuk educative, supportive, dan managerial terhadap kepuasan kerja dan kinerja perawat pelaksana di sebuah rumah sakit di Palu.

Populasi dan sampel adalah seluruh perawat pelaksana yang bekerja di ruang rawat inap rumah sakit di Palu dengan tingkat pendidikan D III Keperawatan yang berjumlah 64 perawat. Besar sampel untuk dokumen askep masing-masing kelompok 56 dokumen. Dokumen diambil dari tiap ruangan secara proporsional dengan menggunakan teknik purposive sampling. 
Pembuatan instrumen variabel kepuasan kerja perawat dengan menggunakan kerangka pikir aspek kepuasan kerja menurut Siagian (2009), yang terdiri dari; otonomi dalam bekerja, variasi tugas, identitas pekerjaan, pentingnya pekerjaan, dan umpan balik. Instrumen kepuasan kerja terdiri dari sebanyak 45 pernyataan unfavorable yaitu terdiri dari pernyataan positif dan pernyataan negatif. Sedangkan, instrumen kinerja perawat pelaksana berdasarkan dokumentasi asuhan keperawatan berupa lembar penilaian dokumentasi asuhan keperawatan yang terdiri dari sebanyak 24 pernyataan yang seluruh item pernyataan bersifat favourable.

Pembuatan instrumen supervisi kepala ruangan rawat inap, mengacu terhadap model supervisi academic menurut Farington (1995) yang terdiri dari kegiatan educative sebanyak 15 pernyataan, kegiatan supportive sebanyak 10 pernyataan, dan kegiatan managerial sebanyak 10 pernyataan. Instrumen ini terdiri dari sebanyak 35 pernyataan unfavorable.

Pengolahan data dilakukan dengan melakukan editing data, coding data, entry data, dan cleaning data pada program statistik di komputer (Hastono, 2007). Analisis univariat dengan menyajikan distribusi frekuensi, analisis bivariat menggunakan uji Chi-square, independent $t$ test, dependent $t$ test, product moment, dan korelasi rank spearman.

\section{Hasil}

\section{Supervisi Klinik Kepala Ruangan}

Pada tabel 1 menunjukkan bahwa perbedaan supervisi klinik kepala ruangan sebelum dan sesudah pelatihan dan bimbingan supervisi klinik pada kelompok intervensi dan kelompok kontrol. Supervisi klinik kepala ruangan pada kelompok intervensi di ruang rawat inap sebelum mendapat pelatihan rata-rata $12,94(36,97 \%)$, sedangkan sesudah mendapatkan pelatihan menjadi rata-rata 33,25 (95\%). Hal tersebut menunjukkan bahwa terjadinya peningkatan sebesar 20,31 (58,03\%). Untuk mencapai skor maksimal 35 diperlukan 1,75 poin. Hasil uji statistik menunjukkan bahwa ada peningkatan yang bermakna pada supervisi klinik kepala ruangan berdasarkan pada persepsi perawat pelaksana sesudah mendapatkan pelatihan dan dibimbing dengan supervisi klinik $(\mathrm{p}=0,000$; $\alpha=0,05)$.

Pada kelompok kontrol sebelum mendapatkan pelatihan nilai supervisi kepala ruangan rata-rata $12,91(36,88 \%)$ dan sesudah tidak mendapat pelatihan supervisi nilai supervisi menjadi 13,43 $(38,37 \%)$ sehingga terjadi peningkatan sebesar $0,53(1,51 \%)$. Untuk mencapai skor maksimal 35 diperlukan 21,57 poin. Hasil uji statistik menunjukkan ada peningkatan tidak bermakna pada supervisi klinik kepala ruangan sesudah tidak mendapat pelatihan $(\mathrm{p}=0,071 ; \alpha=0,05)$.

Tabel 1. Analisis Perbedaan Supervisi Klinik Kepala Ruangan Sebelum dan Sesudah Pelatihan

\begin{tabular}{lllccc}
\hline Variabel & Kelompok & Mean & Beda Mean & Beda SD & p \\
\hline \multirow{2}{*}{ Supervisi } & Intervensi & & & & \\
& Sebelum & 12,94 & 20,31 & 2,494 & 0,000 \\
& Sesudah & 33,25 & & & 0,071 \\
& & & & 1,606 & \\
& Kontrol & 12,91 & 0.53 & & \\
& Sebelum & 13,43 & & & \\
& Sesudah & & & & \\
\hline
\end{tabular}


Perbedaan supervisi klinik kepala ruangan antara kelompok intervensi dan kelompok kontrol sesudah pelatihan supervisi klinik menunjukkan bahwa ada perbedaan yang bermakna ( $p=0,000 ; \alpha=0,05)$.

\section{Kepuasan Kerja Perawat Pelaksana}

Pada tabel 2 menunjukkan perbedaan kepuasan kerja perawat pelaksana antara kelompok intervensi dan kontrol sesudah disupervisi kepala ruangan yang dilatih dan dibimbing dengan supervisi. Hasil menunjukkan bahwa ada perbedaan yang bermakna pada kepuasan kerja perawat pelaksana antara kelompok intervensi dan kelompok kontrol $(\mathrm{p}=$ $0,000 ; \alpha=0,05)$.

\section{Kinerja Perawat Pelaksana dalam Pendokumentasian Asuhan Keperawatan}

Tabel 3 menunjukkan bahwa adanya perbedaan kinerja perawat pelaksana sebelum disupervisi kepala ruangan yang telah dilatih dan dibimbing supervisi klinik. Hasil menunjukkan bahwa skor kinerja pada kelompok intervensi adalah 13,27 dan sesudah mendapatkan supervisi dari kepala ruangan yang telah dilatih dan dibimbing supervisi klinik menjadi 20,61, sehingga terjadi peningkatan 7,34 (30,58\%). Untuk mencapai skor maksimal sebesar 24 diperlukan 3,39 poin. Hasil uji statistik menunjukkan bahwa adanya peningkatan yang bermakna pada kinerja perawat pelaksana sesudah mendapatkan supervisi dari kepala ruangan yang dilatih dan dibimbing dengan supervisi klinik ( $\mathrm{p}=$ $0,000 ; \alpha=0,05)$.
Pada kelompok kontrol sebelum mendapatkan supervisi dari kepala ruangan yang dilatih dan dibimbing supervisi memiliki kinerja sebesar 13,82 dan sesudah mendapatkan supervisi dari kepala ruangan yang tidak dilatih dan dibimbing supervisi menjadi sebesar 14,05, sehingga terjadi peningkatan $0,23(0,96 \%)$. Untuk mencapai skor maksimal sebesar 24 diperlukan 9,95 poin. Hasil uji statistik menunjukkan ada peningkatan yang tidak bermakna pada kinerja perawat pelaksana sesudah mendapat supervisi dari kepala ruangan yang tidak dilatih dan dibimbing supervisi $(\mathrm{p}=$ $0,102 ; \alpha=0,05)$.

Perbedaan kinerja perawat pelaksana dalam pendokumentasian asuhan keperawatan antara kelompok intervensi dan kelompok kontrol sesudah disupervisi oleh kepala ruangan yang dilatih dan dibimbing dengan supervisi klinik menunjukkan bahwa ada perbedaan yang bermakna $(\mathrm{p}=0,000$; $\alpha=0,05)$.

\section{Hubungan Karakteristik Perawat dengan Kepuasan Kerja Perawat pelaksana}

Pada variabel umur nilai $r=0,214$. Hasil uji statistik didapatkan $p=0,09(p>0,05)$. Variabel lama kerja nilai $r=0,188$. Hasil uji statistik didapatkan $\mathrm{p}=0,137(\mathrm{p}>0,05)$. Variabel status pegawai nilai $r=0,076$. Hasil uji statistik didapatkan $p=0,549$ (p>0,05). Jadi, dapat disimpulkan bahwa tidak ada hubungan yang bermakna antara umur, lama kerja, dan status kepegawaian dengan kepuasan kerja perawat pelaksana.

Tabel 2. Analisis Perbedaan Kepuasan Kerja Perawat Pelaksana Sebelum dan Sesudah Disupervisi oleh Kepala Ruangan

\begin{tabular}{llcccc}
\hline Variabel & Kelompok & Mean & Beda Mean & Beda SD & p \\
\hline Kepuasan kerja & Intervensi & & & & 0,000 \\
& Sebelum & 122,22 & 14,719 & 10,504 & 0,386 \\
& Sesudah & 136,94 & & & \\
& Kontrol & & & 4,623 & \\
& Sebelum & 125,75 & 0,719 & & \\
& Sesudah & 126,47 & & & \\
\hline
\end{tabular}




\section{Pembahasan}

\section{Supervisi Klinik Kepala Ruangan Model Akademik}

Supervisi klinik kepala ruangan model akademik yang diterapkan di ruang rawat inap rumah sakit di Palu pada prinsipnya adalah proses pembelajaran dari kepala ruangan kepada perawat pelaksana. Kepala ruangan menyusun program supervisi yang disesuaikan dengan tingkat kemampuan perawat pelaksana dan kondisi klien serta kebutuhan di ruangan.

Bentuk supervisi didesain dalam bentuk kegiatan educative, supportive, dan managerial yang memungkinkan semua perawat berperan aktif dalam kegiatan supervisi. Penerapan supervisi klinik model akademik memacu kepala ruangan dan perawat pelaksana terus mengembangkan kemampuan dalam praktik keperawatan.

Supervisi klinik model akademik dalam penerapannya di sebuah rumah sakit di Palu dilakukan secara terprogram, terjadwal, dan perhatian supervisor bukan hanya pada pelaksanaan praktik keperawatan tetapi juga pada sikap dan tanggung jawab perawat pelaksana dalam praktik profesional.

\section{Supervisi Klinik Kepala Ruangan sebelum Pelatihan dan Bimbingan Supervisi Klinik}

Supervisi klinik kepala ruangan harus mendapat perhatian yang serius dari bidang keperawatan, mengingat resiko dan dampak yang dapat timbul berkaitan dengan supervisi klinik kepala ruangan yang tidak optimal yaitu pelayanan keperawatan yang tidak berkualitas.

\section{Supervisi Klinik Kepala Ruangan sesudah Pelatihan dan Bimbingan Supervisi Klinik}

Kepala ruangan menerapkan kegiatan educative secara tutorial, yaitu kepala ruangan memberikan bimbingan dan arahan kepada setiap perawat pelaksana saat melakukan tindakan keperawatan serta memberikan umpan balik. Kegiatan ini dilakukan secara berkelanjutan untuk mengawal pelaksanaan pelayanan keperawatan yang aman dan profesional

Penerapan kegiatan supportive dilakukan dengan memberikan kesempatan kepada perawat untuk mempresentasikan kasus ketika operan dengan menggunakan standar komunikasi yang efektif. Standar komunikasi efektif yang digunakan antara lain yaitu metode $S B A R$ (Situation, Background, Asessment, Recommendation). Kegiatan supportive mempunyai tujuan untuk mengidentifikasi solusi dari suatu permasalahan yang ditemui dalam pemberian asuhan keperawatan serta dirancang untuk memberikan dukungan kepada perawat agar dapat memiliki sikap yang saling mendukung diantara perawat sebagai rekan kerja profesional sehingga memberi jaminan kenyamanan dan validasi.

Kepala ruangan menerapkan kegiatan managerial dengan melibatkan perawat dalam perbaikan dan peningkatan standar, seperti mengkaji SOP yang ada atau membahas standar pendokumentasian asuhan keperawatan. Kegiatan managerial dirancang untuk memberikan kesempatan kepada perawat pelaksana demi meningkatkan manajemen perawatan klien dalam kaitannya dengan menjaga standar pelayanan, peningkatan patient safety, dan peningkatan mutu.

\section{Pengaruh Pelatihan Supervisi Klinik Kepala Ruangan terhadap Kepuasan Kerja Perawat Pelaksana}

Menurut asumsi peneliti bahwa meningkatnya kepuasan kerja perawat di ruang rawat inap sebuah rumah sakit di Palu disebabkan oleh adanya penerapan dari supervisi klinik model academic, yaitu melalui kegiatan educative, supportive, dan managerial. Pelatihan supervisi klinik telah memberikan kemampuan kepada kepala ruangan untuk menjalankan perannya sebagai perencana, pengarah, pelatih, dan penilai terhadap tugas-tugas yang diberikan kepada para perawat pelaksana. 
Tabel 3. Analisis Perbedaan Kinerja Perawat Pelaksana dalam PendokumentasianAsuhan Keperawatan Sebelum dan Sesudah Disupervisi oleh Kepala Ruangan

\begin{tabular}{llcccc}
\hline Variabel & Kelompok & Mean & Beda Mean & Beda SD & p \\
\hline Kinerja Perawat & Intervensi & & & & \\
& Sebelum & 13,27 & 7,34 & 2,08 & 0,000 \\
& Sesudah & 20,61 & & & \\
& Kontrol & & & 1,04 & 0,102 \\
& Sebelum & 13,82 & 0,23 & & \\
& Sesudah & 14,05 & & & \\
\hline
\end{tabular}

Penerapan supervisi klinik model academic memacu kepala ruangan merancang pekerjaan perawat pelaksana dengan memperhatikan aspekaspek kepuasan kerja, yang meliputi; otonomi dalam bekerja, variasi tugas, identitas tugas, pentingnya pekerjaan, dan umpan balik.

Kegiatan educative dilakukan oleh kepala ruangan yang diawali dengan pembagian tugas yang jelas dan bervariasi sesuai dengan kompetensi dari perawat. Pemusatan pada satu tugas tertentu dapat mengarah kepada tingkat keahlian dan efisiensi tinggi akan tetapi menjadi sangat membosankan. Kebosanan dalam pekerjaan mempunyai dampak yang negatif, yang sering menampakkan diri melalui keletihan, kesalahan dalam pelaksanaan tugas, dan kecelakaan.

Pada kegiatan educative kepala ruangan meng atasi kebosanan dengan mengubah metode pemberian asuhan keperawatan dari metode fungsional menjadi metode tim. Setiap perawat pelaksana diberi tanggung jawab untuk melaksanakan asuhan keperawatan terhadap satu atau beberapa klien sesuai dengan kompetensi. Dengan cara ini perawat lebih tertantang untuk meningkatkan kemampuan dan ketrampilannya melalui arahan, bimbingan, dan umpan balik yang dilakukan oleh kepala ruangan selama kegiatan educative.

Kegiatan supervisi supportive dilakukan kepala ruangan dengan memberi kesempatan kepada perawat untuk mempresentasikan secara singkat kasus ketika operan merupakan bentuk dukungan positif yang diberikan oleh kepala ruangan dan rekan kerja. Perawat akan merasa bangga dapat menunjukkan secara kongkret hasil pekerjaannya. Jika hasil pekerjaan tidak mendapatkan sebuah penghargaan akan menurunkan kepuasan kerja. Meskipun dalam pemberian asuhan keperawatan merupakan hasil dari sekelompok perawat, namun kepala ruangan harus dapat meyakinkan bahwa setiap perawat turut memberikan kontribusi kongkret dalam hasil asuhan keperawatan yang diberikan.

Kegiatan supportive dapat memberi pengalaman belajar yang bermakna dan kesempatan berharga bagi perawat untuk menjembatani kesenjangan antara teori dan praktik keperawatan. Kegiatan supportive dapat mengembangkan kemampuan perawat untuk berpikir kritis dan mengambil keputusan klinik serta kepercayaan diri dalam menjalankan tugasnya (Wink, 1995 dalam Billings \& Judith, 1999). Pada kegiatan tersebut perawat berbagi informasi mengenai pengalaman yang akan muncul, saling bertanya, mengekspresikan perhatian, serta mencari klarifikasi mengenai rencana kerja atau rencana intervensi keperawatan (Billings \& Judith, 1999). Dalam kegiatan tersebut juga perawat dapat mengidentifikasi masalah, perencanaan, dan evaluasi hasil untuk mencari solusi (Reilly \& Obermann, 1999).

Kegiatan supervisi managerial yang dilakukan dengan melibatkan perawat pelaksana dalam pembahasan Standard Operational Procedure (SOP)/ Standar Asuhan Keperawatan (SAK) telah menumbuhkan pemahaman yang penting mengenai bekerja berdasarkan standar yang ada. 
Pemahaman ini sangat penting untuk memacu para perawat pelaksana dalam hal meningkatkan manajemen perawatan klien dalam kaitannya dengan menjaga standar pelayanan, peningkatan patient safety, dan peningkatan mutu.

Hasil analisis lanjut tentang pengaruh pelatihan supervisi klinik kepala ruangan menunjukkan adanya perbedaan yang bermakna pada kepuasan kerja perawat pelaksana terhadap kelompok intervensi dan kelompok kontrol. Dengan demikian hasil penelitian ini membawa pada simpulan bahwa pelatihan supervisi klinik kepala ruangan secara signifikan meningkatkan kepuasan kerja pada perawat pelaksana di ruang rawat inap sebuah rumah sakit di Palu.

\section{Pengaruh Pelatihan Supervisi Klinik Kepala Ruangan terhadap Kinerja Perawat Pelaksana}

Hasil penelitian ini sesuai dengan pendapat White dan Winstanley (2006); Hyrkas, et al. (2006) dalam Clinical supervision a structured approach to best practice (2008) yang menyatakan supervisi klinik berpotensi meningkatkan keahlian dan kemampuan klinik staf yang pada akhirnya akan mempengaruhi pencapaian kesuksesan rumah sakit. Supervisi adalah alat untuk memastikan atau menjamin penyelesaian tugas sesuai dengan tujuan dan standar (Marquis \& Huston, 2010).

Penerapan supervisi klinik model akademik di rumah sakit, melalui kegiatan managerial yang merupakan suatu bentuk supervisi yang memungkinkan kepala ruangan menanamkan rasa tanggung jawab dan kepatuhan perawat pelaksana terhadap standar asuhan yang telah ditetapkan. Melalui kegiatan ini, para perawat duduk bersama untuk memahami, memperbaiki, dan membangun komitmen untuk memperbaiki kinerja berdasar standar yang telah ditetapkan. Melalui kegiatan ini diharapkan ada perubahan sikap dan tindakan perawat dalam melaksanakan asuhan keperawatan.

Penerapan supervisi klinik model akademik di sebuah rumah sakit di Palu telah memacu perawat pelaksana untuk melakukan asuhan keperawatan berdasarkan pada standar yang telah ditetapkan. Perawat melakukan pengkajian secara lengkap dan sistematis yang berdasarkan pada pedoman pengkajian sehingga diagnosa yang ditegakkan berupa diagnosa aktual dan diagnosa potensial. Kemampuan perawat dalam merumuskan diagnosa keperawatan tersebut memungkinkan perawat dapat menentukan tujuan perawatan dengan tepat dan dapat menyusun rencana intervensi secara komprehensif.

Hasil analisis lanjut mengenai pengaruh pelatihan supervisi klinik kepala ruangan, menunjukkan bahwa adanya perbedaan yang bermakna pada kinerja perawat pelaksana antara kelompok intervensi dan kelompok kontrol di ruang rawat inap sebuah rumah sakit di wilayah Palu. Dengan demikian hasil penelitian ini membawa pada simpulan bahwa pelatihan supervisi klinik kepala ruangan secara bermakna meningkatkan kinerja perawat pelaksana di ruang rawat inap rumah sakit di Palu.

\section{Faktor yang Berhubungan dengan Kepuasan Kerja Perawat Pelaksana}

Menurut asumsi peneliti bahwa berapapun umur, lama kerja, dan status kepegawaian perawat pelaksana di sebuah rumah sakit di wilayah Palu tidak berkontribusi terhadap kepuasan kerjanya karena kepuasan kerja dalam penelitian ini dipengaruhi oleh seberapa baik kepala ruangan dalam melakukan supervisi dan merancang pekerjaan dengan memperhatikan aspek-aspek kepuasan kerja yang dibutuhkan oleh perawat pelaksana. Dengan demikian variabel umur, lama kerja, dan status kepegawaian dalam penelitian ini tidak menjadi confounding terhadap kepuasan kerja perawat pelaksana.

\section{Kesimpulan}

Pelatihan supervisi klinik kepala ruangan telah meningkatkan secara bermakna terhadap kepuasan kerja dan kinerja perawat pelaksana di ruang rawat inap sebuah rumah sakit di wilayah Palu. 
Hal ini menyebabkan adanya perbedaan yang signifikan terhadap kepuasan kerja dan kinerja perawat pelaksana antara kelompok intervensi dan kontrol. Umur, lama kerja dan status pegawai perawat pelaksana di ruang rawat inap sebuah rumah sakit di Palu tidak berhubungan dengan kepuasan kerja (HW, NN, EF).

\section{Referensi}

Billings, D.M., \& Judith, A.H. (1999). Teaching in nursing: A guide for faculty. Philadelpia: WB Saunders Company

Clinical Supervision a structured approach to best practice. (2008). National Council for the professional develoment of nursing and midwifery. Ireland. Diperoleh dari http:// www.ncnm.ie/items/1299/85/3167984576 $\% 5$ CClinical\%20Supervision \%20Disc\%20 paper\% 202008.pdf.

Farington, A. (1995). Models of clinical supervision. British Journal of Nursing , 4 (15) 76 - 78.

Hastono, S. P. (2007). Analisis data kesehatan. Depok: Fakultas Kesehatan Masyarakat UI.

Izzah, N. (2003). Hubungan teknik supervisi dan frekuensi kegiatan supervisi kepala ruangan dengan kinerja perawat pelaksana di ruang rawat inap RSUD Batang, Jawa Tengah (Tesis master, tidak dipublikasikan). Program Studi Magister Fakultas Ilmu Keperawatan Universitas Indonesia, Depok, Jawa Barat.
Marquis, \& Huston. (2010). Kepemimpinan dan manajemen keperawatan teori dan aplikasi (Edisi 4). Jakarta: EGC.

Mularso. (2006). Supervisi keperawatan di Rumah Sakit Dr. A. Aziz Singkawang: Studi kasus (Tesis master, tidak dipublikasikan). Program Pasca Sarjana MMR Universitas Gajah Mada Yogyakarta, Jawa Tengah.

Reillyn, E., \& Obermann, M.H. (1999). Clinical teaching in nursing education. Boston: Jones \& Barlet Publishers, Inc.

Saljan, M. (2005). Pengaruh pelatihan supervisi terhada peningkatan kinerja perawat pelaksana di ruang rawat inap Rumah Sakit Islam Jakarta Pondok Kopi Jakarta Timur (Tesis master, tidak dipublikasikan). Program Studi Magister Fakultas Ilmu Keperawatan Universitas Indonesia, Depok.

Siagian, S.P. (2009). Manajemen sumber daya manusia. Jakarta: PT Bumi Aksara.

Supratman, \& Sudaryo, A. (2008). Supervisi keperawatan klinik. Berita Ilmu Keperawatan, I (4), 193-196.

White, E., \& Winstanley, J. (2006). Cost and resource implications of clinical supervision: An Australian perspective. Journal of Nursing Management, 14 (8), 628-636. 